Dr hab. Marta Komorowska-Pudło, https:/ / orcid.org/0000-0001-7222-0182

Institute of Pedagogy

University of Szczecin

\title{
Family-of-origin ties and relationships and how they affect dealing with one's own marital conflicts
}

\author{
Więzi i relacje $w$ rodzinie pochodzenia a radzenie sobie \\ z konfliktami we własnym małżeństwie ${ }^{1}$
}

https://doi.org/10.34766/fetr.v46i2.829

\begin{abstract}
There is a common belief of the importance of the family of origin in the development and acquisition of the psychosocial skills necessary for the realisation of numerous life tasks by all members of a family. This is confirmed by Family Science research on generational transmission process, based on psychological learning mechanisms: observation, imitation, modelling and identification. This article analyses the correlation between the quality of ties and relationships in the family of origin and the methods of coping with conflicts in one's own marriage in adulthood. A study consisting of 250 couples of young spouses was conducted in order to determine to what extent the properties of generational family, measured with the family rating scales based on David H. Olson's Circular Model, are related to the frequency of conflicts in their marriages, what the course of such conflicts are and what effects they have on the quality of the mutual marital relationship. The results obtained confirmed that there is a relationship between coherence, flexibility, the quality of communication in the family of origin as well as the level of one's satisfaction with growing up in these families and the ways of coping with conflicts in one's own marriages in adulthood. In this way, the results show that the process of generational transmission in the families of the respondents indeed took place.
\end{abstract}

Keywords: conflicts, marriage, family, generational transmission, family science

Abstrakt: Powszechne jest przekonanie o znaczeniu rodziny generacyjnej dla rozwoju i nabywania zdolności psychospołecznych do realizowania różnych zadań życiowych wszystkich jej członków. Familiolodzy potwierdzają to $\mathrm{w}$ badaniach dotyczących procesu transmisji pokoleniowej opierającej się na psychologicznych mechanizmach uczenia się: obserwacji, naśladowaniu, modelowaniu i identyfikacji. W niniejszym artykule podjęto analizę związku pomiędzy jakością więzi i relacji $\mathrm{w}$ rodzinie pochodzenia a sposobami radzenia sobie $\mathrm{z}$ konfliktami we własnych małżeństwach w dorosłości. W tym celu przeprowadzono badania wśród 250 par młodych małżonków i określono, w jakim stopniu właściwości rodziny generacyjnej, mierzone za pomocą skal ocen rodziny według Modelu Kołowego Davida H. Olsona wiążą się z częstotliwością konfliktów w ich małżeństwach, z ich przebiegiem i skutkami dla jakości ich wzajemnej małżeńskiej relacji. Uzyskane wyniki potwierdziły dodatni związek spójności, elastyczności, jakości komunikacji w rodzinie oraz poziomu poczucia zadowolenia ze wzrastania $\mathrm{w}$ tych rodzinach ze sposobami radzenia sobie $\mathrm{z}$ konfliktami we własnych małżeństwach $\mathrm{w}$ dorosłości, potwierdzając jednocześnie występujący proces transmisji pokoleniowej w rodzinach respondentów.

Słowa kluczowe: konflikty, małżeństwo, rodzina, transmisja pokoleniowa w rodzinie

\footnotetext{
${ }^{1}$ Wersja w języku polskim na stronie:

https:/ / www.stowarzyszeniefidesetratio.pl/Presentations0/2021-2-09Pudlo2.pdf
} 


\section{Introduction}

Family science's theory and research emphasises the importance of family, their intrinsic qualities of ties and relationships on the development and acquirement of psychosocial skills enabling all members of the family to carry out various tasks in life. On one hand therefore, analysis presented in this article served as a confirmation of an up-todate scientific discourse and on the other hand, introduced detailed conclusions from within a given field of generational transmission and importance of the family of origin's environment in formation of the ability to deal with and solve adulthood's conflicts.

To achieve this, the first part of the article reviews theoretical analysis of the phenomena of generational transmission in the context of ties and relationships in the family of origin, and the ways the young adults brought up in these families deal with conflicts. The second part of the article reviews results of conducted studies presenting correlation between the described family environment and behavioural choices of studied individuals in conflict situations.

\section{Ways of dealing with marital conflicts}

In everyday relations, spouses can experience both satisfactory interactions understood as successful communication and conflicts. They can appear between them with a varied frequency and intensity, and can refer to different topics. Spouses often perceive conflicts in a negative light, as something that can weaken or even destroy a relationship. Meanwhile, marital conflicts are considered by many researchers as unavoidable phenomena (Chełpa, Witkowski, 2015). They are referred to as natural processes within a scope of mutual communication, as important ones in deciding how to solve marital problems (Wilmot, Hocker, 2011).

Conflict is defined inter alia as a discrepancy between partners' view points in the scope of affairs, objectives or ways of carrying them out, as a clash of opposing, mutually exclusive aspirations (Czyżowska, 2009). This indicates that misunderstandings between partners take origin in differences between them as to their judgment or assessment of various matters, phenomena or experiences.

The main reasons for marital conflicts relate to norms and values, mutual expectations, beliefs, habits, ways of thinking and reacting in different situations, needs, wishes, desires relating to given situations, ways of behaving, customs and personality characteristics (Fischaleck, 1990, Wilmot, Hocker, 2011). Spouses' spheres of life in which conflicts arise are mainly as follows: finances, upbringing of children, relationships with a family of origin, friends and acquaintances, addictions, personality and life style, religiosity, sense of responsibility, engagement in individual growth and professional work, 
interpersonal communication, care for intimacy and mutual relations, leisure time, responsibilities of both spouses at home and in respect of family, jealousy, sexual sphere, unfaithfulness, abuse (Da Costa, Falcke, Mosmann, 2015; Fishaleck, 1990, French, Allen, 2021; Mbwirire, 2017; Ryś, 1994).

Spouses solve their conflicts differently. They activate different, contradictory thoughts to each other linked to their emotions and as a result, behaviours leading to escalation, resulting in solution or the continuance of the conflict status. Maria Ryś (1994; see also. Rostowska, 2001) talks about integrating and disintegrating approach to dealing with misunderstandings between spouses. Integrating approach to a conflict allows both parties to concentrate on the subject of disagreement, on facts, to be open to each other, revealing emotions, paying attention on their own and their partner's point of view when looking at the problem at hand, active listening and applying principles of proper interpersonal communication. Problems are being solved immediately after their emergence, in dyad, by taking into a consideration a partner-based way of seeking a satisfactory to both parties solution (Bach, Wyden, 1973, as cited in: Ryś 1994). Spouses exhibiting high level of common positive affect, mutual care and behavioural synchronisation (Oter, Wells, Chen, Brown, Connelly, Levenson, Fredrickson, 2020) and a high level of closeness and autonomy in their relationship (Finn, Johnson, Nyere, 2020) indeed approach conflicts this way. Spouses on a higher level of spiritual and religious intimacy function similarly (Mahoney, Pargament, DeMaris, 2020).

Effects of emerging behaviours in an integrating course of conflict characterise constructive strategies (Wilmot, Hocker, 2011). Amongst the principles of a constructive way of dealing with conflicts, Teresa Rostowska (2001) lists, inter alia, controlling emotions, both parties taking an active engagement in a conversation on the subject of dispute, and the responsibility of both parties for their words and actions, dealing with problems without interference of third parties, applying humour during a talk about conflict, taking into consideration various thoughts, experiences and needs of their partners. According to Maria Ryś (1994), the positive results of such an approach to conflict are an increased level of understanding, trust, closeness, security, forgiveness, reconciliation, clearing of the air and return to balance and cohesion of relationship. Thanks to the aforementioned approach, spouses grow their personality, care about autonomy and their own subjectivity (Chełpa, Witkowski 2015; Fischaleck 1990; Ryś 1994), develop and change what does not work in their relationship (Rostowska, 2001). Utilisation of constructive ways to deal with conflicts enables elimination of occurred dispute between spouses (ibid.). A successful communication between spouses allows them in a conflict situation to seek the reasons for the dispute, to learn about their mutual needs, and as a result, solving difficulties and deepening ties (cf. Haris, Kumar, 2018; Lavner, Karney, Bradbury, 2016.)

Studies of young Chinese married couples confirmed unidirectional associations 
linking daily marital communication or dealing with problems with a quality of their relationship. The latter one is better when constructive ways of communication and solving disputes are used. Studies involving married couples in different phases of their continuous relationship and usage of statements I, You, We, allow to confirm, that a communication in the conflict constitutes basic process of the quality of intimate relationships, which has a fundamental importance to a feel-good factor throughout whole life (Neysari, Bodenmann, Mehl, Bernecker, Nussbeck, Backes, Zemp, Martin, Horn, 2016).

In a disintegrating course of conflict, spouses concentrate on presumptions and guesses, poor communication and mutual hurting. Conflicts have an incremental character and if not attended to regularly, explode with force. Partners are not engaging in common dealing with conflicts, insist on their own rights and more over involve other people in to their own disputes. They do not talk about current events but go back to difficult situations from the past, reproaching various sorrows. They do not reveal their authentic thoughts and feelings (Bach, Wyden, 1973, as cited in: Ryś, 1994). Strategies applied in these types of conflicts are usually destructive (Willmot, Hocker, 2011), and participating parties do not take responsibility for their results (Ryś, 1994). Relationships of people, who deal with conflicts in the aforementioned way, often are dysfunctional, relate to feeling unhappy with each other and conflicts relate to a fundamental matter of their life together (cf. Da Costa et al., 2015). Destructive ways of dealing with conflicts do not lead to results that would satisfy both spouses and often cause an increased tension between partners (Rostowska, 2001). Teresa Rostowska (ibid.) includes in such ways of dealing with conflict, its avoidance, and use of physical or psychological force towards the partner, belittling or downplaying the conflict, minimizing, that is blaming the partner for a conflict, shifting one's own responsibility to others, suppression, e.g. through the screaming reaction of others to the problem, showing regret and resentment towards a partner and manipulation turning attention from the conflict and emotional detachment from the partner. Difficulties in dealing with conflicts, with high probability, are also heightened by the accompanying depression of one, or both spouses. Amongst 1000 subjects there were $47.9 \%$ women in a troubled relationship with their spouses and at the same time suffering from depression (Arora, Deepti, Singh, Lal, 2019). Difficulties in regulating emotions, related to experiencing destructive conflict resolution strategies, further weaken the quality of marital satisfaction of both partners (Omidi, Talighi, 2017).

Fritz Fischaleck (1990) indicates, inter alia, on the so-called hidden (internal) conflicts, which may include, for example, avoiding conversations about them. This may be due to the reluctance to experience open conflicts, the fear of taking up the topic, the belief that it is impossible to solve the problem or hoping for a spontaneous solution to it. Avoiding conflicts, according to the author, does not strengthen relationships, but leads to the emergence of unexplained tensions between the spouses. 
Improper communication, usually associated with expressing unclear messages, incorrect listening to each other and using communication barriers, affect both the formation and difficulties in resolving conflicts (cf. Ryś, 1994). Some couples resolve their conflicts in the presence of other people, thus directly or indirectly involving them in their problems. Such behaviour additionally strengthens the sense of harm of the participants in them (Fischaleck, 1990). Many couples experience verbal or physical aggression during conflicts. It manifests itself in the form of jerking, hitting, throwing objects, kicking, as well as insults, profanity, defamation, irony, etc. It is often associated with uncontrolled emotions, lack of distance and a weakened assessment of the situation (ibid.).

Research on the analysis of post-conflict behaviour of spouses shows that the socalled active repair of relationships (e.g. apologies) and gaining a new perspective (e.g. seeking help from friends) was associated with a faster recovery of positive affectivity in relationships, and avoidance (e.g. pouting or withdrawal) with a slower recovery of affective well-being, making it difficult to establish intimate bonds (Parsons, Prager, Wu, Poucher, Hansen, Shirvani, 2020). Forgiveness, even in the event of divorce, is an important response to reducing the intensity of conflicts between ex-spouses and reducing the traumatic impact of parents' divorce on the development of their children (Kluwer, Van der Wal, Visser, Finkenauer, 2020). On the other hand, the use of a strategy of coercion (enslavement) in resolving marital conflicts has a negative impact on relationships. Coercion is associated with dissatisfaction in the relationship, instability and violence between partners ( $\mathrm{Ha}$, Otten, McGill, Dishion, 2019).

\section{Generational transmission process in family and the ways adult children deal with conflicts in their own families}

The quality of ties in the family of origin, the relational processes taking place in it, and especially between parents, are important models for building one's own relationship and family in adulthood. Children learn in a natural way, inter alia through the social learning processes about the scope of functioning in marital and parental roles, inclusive of communication and conflict resolution. They built a pattern based on generational transmission, in case of which, emphasises Teresa Rostowska (1995, p. 8), "one can talk about similarity, compatibility or even continuity of behaviours, not only in behavioural terms, but also in terms of numerous psychological manifestations presented in the intellectual, emotional and social spheres, and therefore in a broadly understood personality". Artur Doliński (2004) talks about the continuous manner of generational transmission, whereby patterns are reproduced from one generation to the next or about intergenerational discontinuities whereby patterns are actively transformed in adulthood. He also talks about desired transmission consisting of the family of origin's positive behavioural patterns, and 
undesired ones, whereby negative patterns are adopted. Following this distribution certain behavioural patterns are not always passed to the next generations.

The process of analysed transmission is most influenced by the family life climate, quality of family members ties and interactions, the socialisation process and type of life situations they all participate in (see also. Rostowska, 1995; Sokolovic, Leckie, Browne, Jenkins, 2021). Researchers observe the phenomenon during the process of transmission of more frequent adoption of destructive, stressful or traumatic events observed in childhood family experiences (cf. Quinton, Rutter, 1984, as cited in: Rostowska, 1995). It is particularly evident in the example of attachment styles in family environments that strongly condition psychosocial abilities to build relationships with others, including how to deal with conflicts (cf. Cassibba, Coppola, Sette, Curci, Costantini 2017). Also, research confirms a higher level of physiological reactions in a stressful conflict situation in spouses with an avoidant attachment style (Kazmierski, Beam, Margolin, 2020).

The intergenerational process of transmission linked to personality moulding, are most effectively conditioned by observation and, inter alia, corresponding with it, an example of a parenting person, imitation, identification and modelling (see also. Bandura, 2007). To a large extent, it is through modelling that a child adopts patterns of communication from their parents and afterwards imitate in their own family. It also transpires that usually from the same sex parent a child adopts a dominant type of communicational behaviour and from the opposite sex parents a recessive one (HarwasNapierała, 2008). Behaviours adopted from parents are to a large extent reinforced through the process of identification with a parent whereby their personality resembles that of mother or father (Meichenbaum, 1979, as cited in: Rostowska, 1995). When the parents' marital relations are right, the child's process of identification is easy, however if they are in conflict or demean each other, this identification is difficult and may take the form of identification e.g. with an aggressor in order to cope with anxiety (Gałkowska, 1999).

The family of origin is a fundamental environment- a matrix for creating interpersonal relations (see also. Stewart, Logan, 2021). Its influence relates, inter alia, to emerging patterns and narration about the perception of the world, oneself, others and relationships with others. (Young, Klosko, Weishaar, 2015). The quality of parents' marriage and therefore the character of their interactions, constitute the main source of the aforementioned relational patterns between spouses in their own relationships. Many researchers confirm that children in adulthood reveal similar styles of communications and behaviours to those observed of their parents. The quality of marital communication determines the quality of communication in the whole family and constitutes the main and starting pattern of communication between all members of a family living together and also a pattern often adopted from the families of origin into their own (Overbeek, Stattin, 2007). Marta Komorowska-Pudło's (2019) research shows that $60 \%$ of young adults repeat the ways 
in which their parents communicate between each other in their own marriages and the most often repeated were demeaning behaviours present during conflict situations. At the same time, the better quality of communication observed in childhood between parents in terms of support and engagements, with little signs of demeaning, the better was a quality of marital communication in their own relationships, sense of a good match, mutual bond, love and sexual satisfaction. When both spouses repeat incorrect behaviours of their parents and are not breaking continuity of generational transmission, they can experience difficulties in building successful interactions with each other (Chaumier, 2007, as cited in: Bieńko, 20082009). By the same token, growing up in homes where parents created happy relationships, with a high probability, their adult children would do the same (Knoester, 2003).

The phenomenon of generational transmission in the family also relates to the ways parents solve their conflicts and it is exactly through observing parental conflict resolution abilities that a child learns how to imitate, and then apply lessons learned (Poręba, 1981, as cited in: Ryś, Greszta, Grabarczyk, 2019). Research shows, the more constructive conflict resolution by parents the children observed, the more constructive their own narratives about human disputes resolution were (Lawson, Speidel, Fondren, Cummings, Valentino, 2020). Confirmed by researchers the fact of conflicts' transmission from marital dyad to parents-children and vice versa dyad, and consequently children's inclusion in pan family conflicts, can result in the emergence of difficulties by married couples to deal with problems constructively and also a future inclusion of children into their own conflicts (Mastrotheodoros, Van Lissa, Van der Graaff, Deković, Meeus, Branje, 2020). Researchers agree that the coercive strategies during marital conflict resolution usually first appear in the family of origin and then continue in adult romantic relationships. Longitude studies confirmed that destructive parental behaviours activated antisocial and deviant behaviour in adolescent children and also the use of violence in intimate adulthood relationships (Ha et al., 2019).

Taking into consideration the fact that parents do pass communicational patterns onto their children also in terms of conflict resolutions, Wiliam W. Wilmot and Joyce L. Hocker (2011) identified three types of families: avoidant, cooperative and aggressive during conflict situations. They emphasized transition of the aforementioned types to their own families in adulthood. Avoidant families ignore conflicts and do not reveal emotions and everyone has to find oneself in those situations on their own. Cooperative families work amongst themselves and everyone is engaged in solving the conflict in a constructive way, by maintaining active listening, self-disclosure and mutual support. In aggressive families, the participants in the conflict are vocal and honest in revealing their needs and emotions however do it in a brutal way what leads to the escalation of dispute rather than its resolution. The authors emphasize that in situations where spouses transmit different patterns of communication from the families of origin, constructive conflict resolution will be 
very difficult without breaking generational transmission process. Similarly, Rudolph H. Schaffer (2021) points out that in a situation where children observe, first hand, destructive ways of conflict resolutions that take place between their parents, especially when they are verbally or physically aggressive towards each other, they learn to discharge their emotions in a negative way and they capture the image of negative behaviour, often repeated in the future. Many researchers agree that family conflict can be continuous and perpetuate itself over the next generations where it may also be more intense and harmful than the conflict experienced by one generation (Rothenberg, Hussong, Chassin, 2018).

\section{Emotional bonding and family relations in the David H. Olson's Circular Model}

Family systems researcher, Olson, diagnosed the family using the so-called Circular Model (Kouneski, 2000). He observed, inter alia, the extent to which its members relate to each other and how they behave (Olson, McCubin, Barnes, Larsen, Muxen, Wilson, 1989, as cited in: Kouneski, 2000), i.e. what is the level of coherence and flexibility in the family and how family communication takes place (ibid.). He also focused on the analysis of the level of life satisfaction in a given family (Olson, 2013).

The quality of family life fundamentally depends on the level of its cohesion. Speaking about it, Olson $(2000,2013)$ paid special attention to the quality of the emotional bonding between family members, mutual support, psychological boundaries set between them, the motivation to spend time with each other and mutual friends, the amount and manner of spending leisure time together, and community decision making. He distinguished three types of families in terms of cohesion. The first type is those that are characterized by a balanced area of cohesion. Depending on the level of this cohesion, there may be so-called separated families (cohesion level: low to moderate), connected (consistency level: moderate) and strongly connected (cohesion level: moderate to high). The other two types of families Olson (ibid.) are characterized by an unbalanced area of cohesion, at the either extremes very low (disengaged) or very high (enmeshed).

Balanced family systems (separated and connected types) tend to be more functional across the life cycle. It manifests itself in a balance between separateness and emotional closeness and togetherness (Olson, 2000). As family members exercise some level of separateness i.e.: they have their own acquaintances, certain activities and interests exercised independently, they also have time together with mutual friends, some important joint decision making and marital support. They are characterised by emotional closeness, loyalty and a sense of community (ibid.). The external boundaries in such families are partially open and internal ones are partially or entirely open, while the intergenerational boundaries and clear ones (Olson, McCubbin, 1982, as cited in: Radochoński, 1999). Olson (2000, 2013) indicates that balanced family systems are optimally functional in all cycles of family life and 
are healthy. Depending on whether the balanced cohesion is more or less intense, this closeness, community, autonomy, having the shared friends, the ways of spending leisure time and loyalty may be characterised by lower or higher level of cohesion however within the limits of this balance.

The problems in the functioning of families start when the cohesion is either too high or too low (ibid). In enmeshed families, at the extreme high level of cohesion, emotional closeness and loyalty do not allow a satisfactory separation from individual members of the family. There is a lack of personal separateness and little private space is permitted. There is a high level of interdependence, emotional hypersensitivity and control. It is similar with making decisions, developing interests and activities. There is little room for autonomy, individual spaces, ways of life and decisions. The individuals' energy is concentrated mainly on family matters (Olson, 2000). The external boundaries are closed, and the internal and intra-generational ones are blurred (Olson, McCubbin, 1982, as cited in: Radochoński, 1999). In family systems characterised by extremely low levels of cohesion i.e. in disengaged families, individual members of the family live in an emotional separateness and a limited closeness. They rarely share leisure time, rarely pursue common interests and have very little or no shared friends. They are striving for independence, making decisions independently and often different to those made by other family members. They prefer separate spaces; boundaries between each other are closed and they keep intergenerational boundaries rigid. They more often open up to the outside world where they look for self-realization, satisfying their needs and ways to solve problems. In such homes, family members rarely support each other, are not very sensitive to the problems of others, are not loyal, unanimous and hardly engaged in their home affairs (Olson, 2000).

The quality of mutual family relations is analyzed by Olson (as cited in: Margasiński, 2011) by examining the so-called flexibility, originally called adaptability. It includes measurement of the roles performed and the degree of changes in family leadership, rules of mutual communication and conflict resolution (Olson, 2000, 2013). The analysis of this dimension makes it possible to distinguish families with balanced and unbalanced flexibility. In the group of families with balanced flexibility, there are three types: inflexible, so-called structured (level of flexibility: low to moderate), moderately flexible (level of flexibility: moderate) and highly flexible (level of flexibility: moderate to high). Among families with unbalanced flexibility there are rigid families with an extremely low level of this dimension and chaotic families with an extremely high level of flexibility (ibid.).

In a properly functioning family with a balanced level of flexibility, stability and change are in balance with each other. When necessary, changes are adopted naturally, and stable roles, rules and leadership in the family are democratically negotiated and adapted to new circumstances (Margasiński, 2011), the age of family members and its current structure (Olson, 2000). Problems in these families are solved effectively, constructively and mainly 
based on positive feedback (Olson, McCubin, 1982, as cited in: Radochoński, 1999). With a balanced high level of flexibility, there is equality in leadership that is subject to smooth change. Relationships are based primarily on democracy, forbearance, closeness, clear intergenerational boundaries and negotiability of rules, consequences and decisions. When balanced family flexibility is low or moderate, leadership is dominated by authoritarianism that allows for elements of equality, some degree of democracy, and occasional forbearance. The generational boundaries are clear, decisions are made mainly by parents, their closeness to their children is partial, and the rules are firm, albeit with the possibility of exceptional concessions (Olson, 2000).

Chaotic families, with an extremely high level of flexibility, base their functioning on limited and inconsistent leadership. Parent-child relationships are too close and generational boundaries are blurred. Parents use ineffective control over their children, are very understanding, inconsistent, and introduce variable or implicit rules. As a result, they bear a high risk of educational failure. There are no clearly defined roles in these families as they change frequently. Problems are solved with great difficulties, incl. due to endless negotiations, impulsiveness of decisions and passivity or aggressiveness in expressing opinions. In rigid families, with different levels of flexibility, extremely low, life is based on authoritarian leadership. Parents are completely incomprehensible, impose their decisions on others, strongly control their children, apply rigid and rigorous rules as well as strict and unchanging consequences. The roles are stereotypical and result from rigid generational boundaries, which allow for little closeness of parents with their children (ibid.). Such a family has difficulties in solving problems, is unable to negotiate, and bases its relations on negative feedback and passively or aggressively expressed opinions (Olson, McCubin, 1982, as cited in: Radochoński, 1999). Both types of families - chaotic and rigid - are problematic families (Olson, 2000, 2013).

As mentioned above, Olson also described the family on the basis of an analysis of the ways in which its members communicate. Communication, in his opinion, largely influences family cohesion and flexibility, and includes "positive communication skills" (Olson, 2013, p. 7), sharing plans, thoughts and feelings between all members of the family (Olson, Barnes, 2004, as cited in: Margasiński, 2013). Observation of communication in the family allows to determine how its members listen to each other, how they talk to each other, the manner of their communication, is it based on respect and empathy, do they share feelings and self-reflections and thoughts relating to the family, and whether it creates the ability to solve problems (Olson, 2000).

In the Circle Model, family communication levels can be defined as low, correct, or high. With low communication levels, family members rarely develop empathy and attentive listening. They speak for others more often, rarely about themselves, about feelings and relationships. Messages are opaque, inconsistent and / or unclear. Often non-verbal 
communication does not relate to the verbal one. The interlocutors do not maintain thematic continuity; they lose the main threads of the conversation, introduce inadequate topics, and use communication barriers. They also often do not respect the feelings or signals sent to them by others, or openly disregard their interlocutors. In correct family communications, empathy, listening carefully, and speaking for oneself and for others are sometimes revealed. Sometimes there are conversations about their own experiences, feelings and relationships. Communication is more transparent than in the previous type of families, although there are also inconsistencies, breaks in thematic continuity, lack of logic, non-verbal distracting messages, inadequate changes to the topics of conversation, and a lack of respect towards interlocutors. In homes where the level of communication is high, the basis for conversations is empathy and careful listening, respect for the feelings and signals sent by other people, talking about yourself and for yourself, and rarely for others, revealing your own feelings and needs. There is a thematic continuity in conversations, adequate variability of conversation topics, and coherence of verbal and non-verbal communication (ibid.). Research shows that in families with balanced cohesion and flexibility, communication is more effective (Barnes, Olson, 1985, as cited in: Margasiński, 2011), and in homes with unbalanced systems, communication is poor (Olson, 2000). Most often, the quality of communication in the family strengthens the character of cohesion and flexibility (Radochonski,1999).

Olson and Marc Wilson (as cited in: Olson, 2004) created a family satisfaction scale that covers the level of fulfilment and sense of happiness of family members in a mutual relationship. In the Circular Model, Olson (ibid.) translates the level of satisfaction with family life into the level of satisfaction in the abovementioned dimensions - consistency, flexibility and communication. He also assumed that the higher the cohesion and flexibility index and the level of communication in the family, the higher the level of satisfaction with family life, and the higher the level of satisfaction with the quality of life in one's own home, the better mutual communication between family members (Margasiński, 2011).

On the basis of several hundred studies on family measurements using the scales used in the Circular Model, it has been confirmed that the most efficiently functioning families are characterized by balanced cohesion and balanced flexibility as well as the highest quality of communication and the associated high level of satisfaction with life in a given family (Kouneski, 2000). A highly problematic family with difficulties in functioning is characterized by unbalance, i.e. extreme levels of both dimensions, that is, disengagement or enmeshment, and rigidity or chaos. In such a family, communication is not satisfactory, and life satisfaction is low (Barnes, Olson, 1986, as cited in: Kouneski, 2000). 


\section{Cohesion, flexibility and communication in a family and their impact on acquiring the ability to deal with conflicts in the most up to date research}

When analysing the correlation between the assessment of the family of origin and the ability to deal with conflicts in adulthood in one's own marriage, one should take into account various aspects that may be associated with the acquisition of abilities that facilitate or hinder communication with partners in conflict situations. Following various conclusions by researchers it can be concluded that upbringing in homes characterised by good communication, balanced cohesion and flexibility, relate to growing up with a given experiential wealth, enabling a constructive and integrative style of marital conflict resolution. It allows on one hand an acquisition of communicative abilities e.g.: via mechanisms of social learning, and on the other hand, the development of personality traits favouring maturity in functioning in relationships. Meanwhile being brought up in an unbalanced family systems, with a low level of communication and the aforementioned behaviours rarely occurring in such families, makes the possibility for their growing children to adopt the correct methods of conflict resolution unlikely. At the same time, personality traits emerging in children brought up in such family systems (inclusive of a low self-esteem, a low level of emotional intelligence, low level of agreeableness and insecure attachment style) make it difficult for a child to build satisfactory relationships based on good communication with others.

In the search for answers about the correlation between the assessment of ties and relations in the family of origin and the ways of dealing with conflicts, some hypotheses based on the results of studies in the field of the acquisition of psychosocial abilities by members of the observed families, can be formulated. Olson (1989, as cited in: Kouneski, 2000) found that a high level of cohesion, flexibility and communication is associated with the coping skills of family members in stressful situations of change and with the better communication skills. He also pointed out that balanced families have the resources and skills to change their systems in the right way, towards cohesion and flexibility (Olson, 1979, as cited in: Margasiński, 2011). They can adapt to emerging new conditions and deal with the crisis effectively (Olson, 2000). Therefore, it can be reasoned, that a high level of adaptability to the changes and acquisition of the ability to cope with difficulties arising in circumstances of change, formulate the basis for coping with problem situations such as conflicts with other people in life. Getting support and a clearer message from others in balanced families as opposite to the unbalanced ones as shown by Barnes and Olson studies (1986, as cited in: ibid.) on the quality of communication between a parent and a teenager, could be the foundation for constructive ways of communication between spouses in conflict resolution. It was also observed that family closeness and responsive communication between parents and children correlated with the development of empathy in adolescents (Henry, Sager, 
Plunkett, 1996, as cited in: Kouneski, 2000), an extremely important ability to build intimate relationships supported by a high level of marital mutual understanding. Confirmed by King (1989, as cited in: Kouneski, 2000), the correlation between high family cohesion and the development of maturity in adolescents, and boys particularly, also with moulding their internal sense of control, indicates that adults with such characteristics will most likely strive for constructive and integrative approach to marital conflicts. Polish researchers have observed the correlation between certain personality traits, necessary to dealing with conflicts, with growing up in balanced family systems. These characteristics are a high level of emotional intelligence (Korol, 2015; Martowska, 2015), social competences and sense of well-being (Martowska, 2015).

In the case of a low level of cohesion, flexibility and communication in the family, all the above-described correlations, indicate a lower level of communication skills and the ability to cope with stress and changes (Olson, 1989, as cited in: Kouneski, 2000). It can therefore be reasoned that during conflict situations people from such homes will find it difficult to constructively deal with them. On the basis of many studies, Olson (2000) concluded that unbalanced families may not have the resources necessary to cope with change that is associated with greater difficulties in adapting to the crisis. In difficult times of high stress, unbalanced systems usually stay with the established ways of coping, which very often in the past turned out to be ineffective thus gathering negative stress experience. At the same time, many studies confirm that extreme levels of cohesion and flexibility are linked to family dysfunctionality (Margasiński, 2011), although Olson (2000) demonstrated in some cultural groups (e.g. Mormons or Latinos) cohesion and flexibility extremes were not necessarily linked to families' dysfunctionality. Important measure of their functionality can be an appraisal of their sense of family satisfaction. Considering that more people, including children and adolescents, grow up in families with extreme levels of family cohesion and flexibility, compared to those brought up in balanced family systems, experience social functioning disorders, it can be reasoned that these environments are less able to grow the ability to build relationships with themselves and with others. In such families, there has been observed less mutual support, as well as increased depressive symptoms in both parents (Colvin, 1984; Manne, Lesanics, Meyers, Wollner, Steinherz, Redd, 1995, as cited in: Kouneski, 2000) and children (Warner, Mufson, Weissman, 1995; Kashani, Allan, Fahlmeier, Rezvani, Reid, 1995, as cited in: ibid.), lower levels of well-being (Martowska, 2015) and emotional intelligence (Korol, 2015), and problems with socio-emotional adaptation (Martowska, 2015). More behavioral problems requiring clinical treatment were observed in members of unbalanced family systems (Smets, Hartup, 1988; Marett, Sprenkle, Lewis, 1992, as cited in: Kouneski, 2000; Smets, and Hartup, 1988, as cited in: Margasiński, 2011), i.e. abuse of alcohol and drugs (Smart, Chibucos, Didier, 1990, as cited in: ibid.), problems with criminal law and prison sentences (Radochoński, 1999). Youth appraisals and 
triangulation into conflicts are key mechanisms by which inter-parental conflict places youth at risk for psychological maladjustment (Fosco, Bray, 2016). At the same time, it turns out that involving adolescents in conflicts between their parents impairs their assessment of the level of family cohesion in which they grow up (McCauley, Sloan, Xia, Fosco, 2021).

The effects of children's involvement in marital conflicts (both active and passive) are extensive and their effects can be direct and long term. Observed in research the sense of threat by conflicts with peers, diminished openness to their support, increased symptoms of social anxiety and a sense of loneliness as a result of observing conflicts between parents by adolescents (Weymouth, Fosco, Mak, Mayfield, LoBraico, Feinberg, 2019), can, at a later time, be a factor impairing psychosocial abilities to deal with relational difficulties. After several years of the observation of children who in their infancy passively participated in parental conflicts, researchers noticed a strong surge of aggression in $7 \%$ of a studies sample, and a weak surge of aggression in 19\%, while they did not notice any in children growing up in good family environments (Jambon, Madigan, Plamondon, Jenkins, 2019). There is strong evidence suggesting that family relations' characteristics and especially marital conflicts, can effect adolescence development. Their physical health and well-being were greater where their parents' marriage experienced fewer conflicts (Seiter, Lucas-Thompson, Graham, 2019). Experiencing the observation of conflicts constructively resolved by parents is usually associated with a positive educational atmosphere and impacts the child's adaptive abilities, whereby the observation of destructive conflict resolution, alongside problematic parenting practices, is linked to the child's externalized symptoms (Warmuth, Cummings, Davies, 2020). It can be reasoned that sustained involvement (direct and indirect) in parents' conflicts may model externalized behaviours in children (e.g. open and uncontrolled display of resentment, anger and aggression) that at a later time are utilised when communicating and dealing with conflict situations. The impact of conflicts between parents on the increased risk of externalizing problems by children and adolescents is related to, inter alia, to their ability to coordinate physiological stress response. It turns out that poor coordination of the sympathetic and parasympathetic nervous systems exposes children to a greater risk of externalized behaviour in the context of parents' marital conflicts (McKernan, LucasThompson, 2018). Laboratory results of adolescents growing up in a high level of parental conflict homes provided evidence of their high sensitivity to stressful situations (e.g. they had a higher level of cortisol compared to those growing up in families with a low level of conflict) (Lucas-Thompson, Granger, 2014). Children's entanglement in their parents' conflict causes them increased psychological problems (both externalized and internalized). The emotional reactivity of children to conflict between their parents turned out to be a much stronger predictor of their mental maladjustment when they were strongly enmeshed in conflicts. Additionally, the developmental benefits versus the price paid for a parental conflict entanglement varied with the emotional reactivity. Being enmeshed in such conflicts 
predicted increased psychological problems in children experiencing high emotional reactivity and a decrease in psychological problems when they showed low emotional reactivity (Davies, Coe, Martin, Sturge-Apple, Cummings, 2015). Research has also confirmed that children's observation of conflicts and hostility between parents is associated with a higher level of externalized behaviour and emotional reactions as well as a nonconstructive conflict behaviour in later years (Parry, Davies, Sturge-Apple, Coe, 2020; Van Eldik, De Haan, Parry, Davies, Luijk, Arends, Prinzie, 2020). All of these properties suggest a highly likely occurrence of difficulties in self-educating their ability to constructively solve problems arising in their lives, inclusive of conflicts with others. Should these ill-conceived conflict resolution resources prevail, one can reason that reactions of emotional turmoil during disputes with loved ones will be more frequent and can be linked to destructive ways of reacting and a disintegrating character of marital conflict resolution.

\section{Methodological foundations of the presented research}

The studies were conducted in the West Pomeranian Province in 2018-2019. 250 married couples aged 25-35 took part in them.

The research problem to be studied was formulated as the following question: To what extent does the quality of family ties and relations in which the respondents grew up, determine the ways of dealing with conflicts in their own marriages? It was hypothesized that being brought up in a high level of cohesion, flexibility, and good communication family, correlating at the same time with a strong sense of satisfaction of growing up in such families, there is a lower frequency of marital conflicts, and when they do occur, there are in built constructive ways of solving them and a positive conflict resolution, leading to a further marital integration. However, experiencing a low level of cohesion and flexibility as well as poor communication in the families of origin, correlating at the same time with family life dissatisfaction, is linked to the emergence of difficulties in securing respondents' fair resolution of marital conflicts, and the emergence of negative effects that further disintegrate the relationship between spouses. Two variables were determined, the dependent one, i.e. the ways of dealing with marital conflicts, and the independent one, i.e. the quality of ties and relationships in the family of origin, retrospectively appraised by respondents. The results of the research were presented by means of a percentage scale and by measuring the correlation coefficients between the variables. Statistical analysis to determine the relationship between the variables was carried out using the Spearman correlation coefficient $\rho$, and to show the differences in the variables depending on gender, using the MannWhitney U index.

Three tools were used to conduct the research. The first was the questionnaire by Maria Ryś (1994) 'Family conflicts' (Konflikty w Rodzinie), with two scales inbuilt. The first 
allowed for the assessment of the course of conflicts in the respondents (whether they were integrating or disintegrating), the second allowed for the determination of the effects of the conflicts they experienced (whether they were positive or negative effects).

The second tool was the David H. Olson FACES IV (Flexibility and Cohesion Evaluation Scales) questionnaire - Family Assessment Scales (SOR), adapted by Andrzej Margasiński (2011), and modified to study ties and relations in the family of origin. The respondents retrospectively assessed the quality of the family in which they grew up. The measurement related to family cohesion and flexibility, the quality of communication in the family, and the level of life satisfaction in a given family. The third tool, a questionnaire designed by the author, measured various methods of conflict resolution. The following groups of behaviour during conflicts were distinguished: correct behaviours, consistent with constructive conflict resolution strategies, and poor behaviours indicating destructive strategies for dealing with disputes, i.e. physical aggressive behaviour, verbal aggressive behaviour, communication barriers, inability to deal with emotions, escape behaviour, competitive behaviour and third parties engagement in the conflict. The respondents specified the frequency of behaviour's indicated in the questionnaires that occur to them in situations of experienced conflicts with their spouses. The causes of marital conflicts and a frequency of conflict situations in their relations were also studied.

\subsection{The quality of ties and relations in the family of origin and the marital ways of dealing with conflicts in own research}

The analysis of the research results began with determining the level of cohesion and flexibility in respondents' family of origin, as well as the quality of communication in these families and the level of satisfaction of growing up in them. This data is presented in Table 1.

Table 1a. The Family-of-Origin scale of the studied men and women

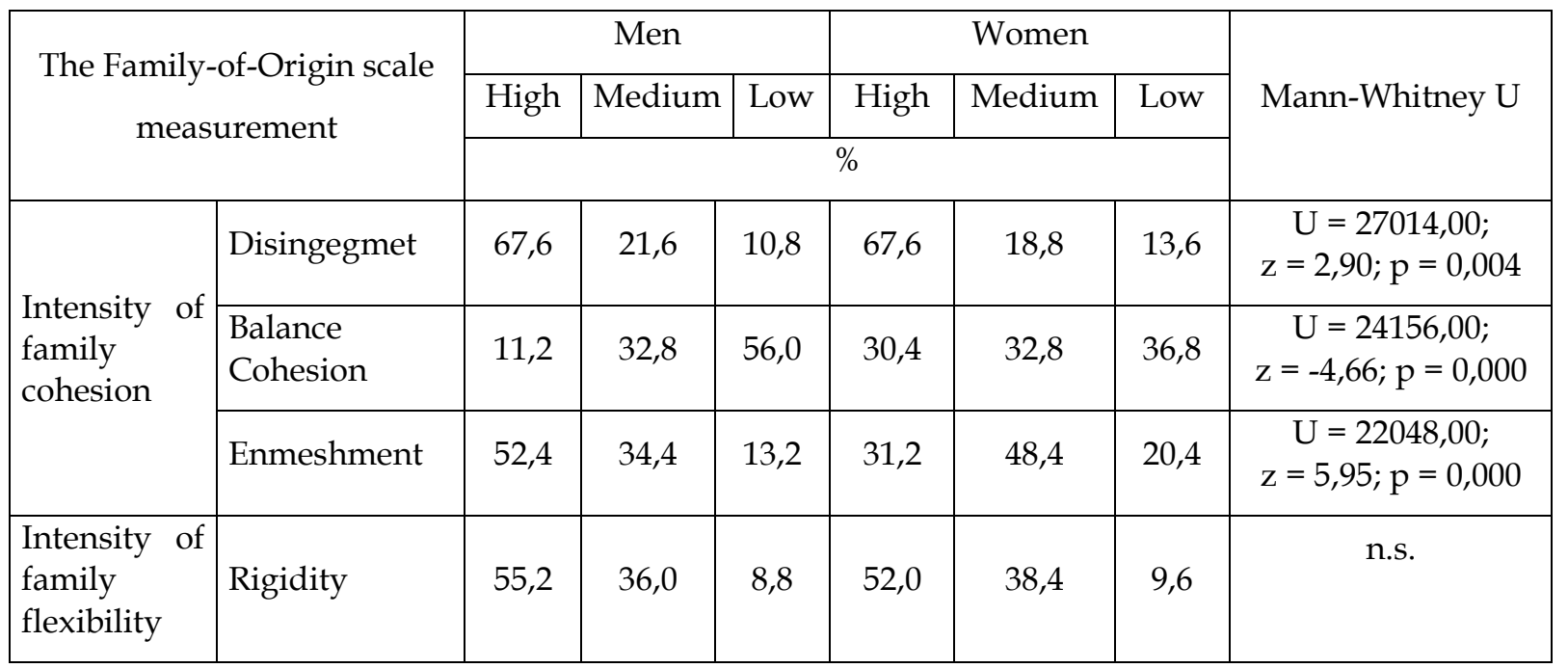


Table 1b. The Family-of-Origin scale of the studied men and women

\begin{tabular}{|c|c|c|c|c|c|c|c|c|}
\hline \multirow{3}{*}{\multicolumn{2}{|c|}{$\begin{array}{c}\text { The Family-of-Origin scale } \\
\text { measurement }\end{array}$}} & \multicolumn{3}{|c|}{ Men } & \multicolumn{3}{|c|}{ Women } & \multirow{3}{*}{ Mann-Whitney U } \\
\hline & & High & Medium & $\overline{\text { Low }}$ & High & Medium & Low & \\
\hline & & \multicolumn{6}{|c|}{$\%$} & \\
\hline \multirow{2}{*}{$\begin{array}{l}\text { Intensity of } \\
\text { family } \\
\text { flexibility }\end{array}$} & \begin{tabular}{|l|} 
Balanced \\
Flexibility
\end{tabular} & 15,2 & 35,6 & 49,2 & 38,0 & 41,6 & 20,4 & $\begin{array}{c}U=227619,00 \\
z=-2,53 ; p=0,011\end{array}$ \\
\hline & Chaos & 64,4 & 24,4 & 11,2 & 38,8 & 38,4 & 22,8 & $\begin{array}{c}U=22205,00 \\
z=5,85 ; p=0,000\end{array}$ \\
\hline \multicolumn{2}{|c|}{ Communication in Family } & 18,8 & 29,2 & 52,0 & 32,4 & 29,6 & 38,0 & $\begin{array}{c}U=27965,5 \\
z=-2,32 ; p=0,020\end{array}$ \\
\hline \multicolumn{2}{|c|}{ Life Satisfaction in Family } & 34,8 & 31,6 & 33,6 & 66,4 & 12,8 & 20,8 & $\begin{array}{c}\mathrm{U}=27334,00 \\
\mathrm{z}=-2,70 ; p=0,007\end{array}$ \\
\hline
\end{tabular}

The respondents participating in the research came from families where the atmosphere was mostly unfavourable to build satisfactory relationships and ties with its members (Table 1). Only every ninth man (11.2\%) and less than one third of the surveyed woman $(30.4 \%)$ grew up in homes with a high - optimal level of balanced cohesion. A large group of respondents grew up in families with a high level of disengagement, i.e. in families with little warmth or closeness (67.6\%), and a little less than half of those in homes with an atmosphere of enmeshment, i.e. extreme closeness hindering the process of individuation and separation from family members (52.4\% of men and $31.2 \%$ of women). A small group of respondents grew up in families of a high level of balanced flexibility $(15.2 \%$ of men and $38 \%$ of women). A large group of respondents assessed their family of origin as functioning at a high level of rigidity, where they grew up in an atmosphere of authoritarianism $(55.2 \%$ of men and $52 \%$ of women) or as functioning at a high level of chaos, characterized by an atmosphere of inconsistency and instability of rules and roles $(64.4 \%$ of men and $38.8 \%$ of women). Every fifth surveyed man (18.8\%) and every third women $(32.4 \%)$ stated that in their families, communication was carried out in a highly satisfactory manner, and in more than half of the families of men (52\%) and slightly more than a third of women (38\%), this communication was assessed as unsatisfactory. Only one-third of men (34.8\%) and twothirds of women $(66.4 \%)$ were satisfied with life in their family of origin. In the vast majority of family assessment scales, men more often than women indicated a less correct family environment in which they were brought up.

In the second part of the research, the respondents were asked to define the frequency of conflicts occurring in their marriages, as well as, to describe the trajectory of their conflicts. The repercussions of conflict resolution were also studied (data on this subject are presented in Table 2). 
Table 2. Distinctiveness of marital conflicts

\begin{tabular}{|c|c|c|c|c|}
\hline \multirow{2}{*}{\multicolumn{2}{|c|}{ Distinctiveness of marital conflicts }} & Men & Women & Both \\
\hline & & \multicolumn{3}{|c|}{$\%$} \\
\hline \multirow{3}{*}{ Frequency } & A few times a year & 42,9 & 44,0 & 43,5 \\
\hline & $\begin{array}{l}\text { A few times a } \\
\text { month }\end{array}$ & 42,1 & 42,5 & 42,3 \\
\hline & A few times a week & 15,1 & 13,5 & 14,3 \\
\hline \multirow{3}{*}{ Trajectory of conflict } & Integrating & 58,8 & 62,4 & 60,6 \\
\hline & Unspecified & 18,9 & 15,8 & 17,4 \\
\hline & Desintergrating & 22,3 & 21,8 & 22,1 \\
\hline \multirow{3}{*}{ Effects of conflict } & Positive & 71,9 & 70,6 & 71,3 \\
\hline & Unspecified & 18,9 & 16,0 & 17,5 \\
\hline & Negative & 9,2 & 13,4 & 11,3 \\
\hline
\end{tabular}

In the studies of married couples, small, statistically insignificant differences between women and men were found when measuring the specificity of their conflicts (Table 2). The spouses experienced conflicts with varying frequency. Every seventh couple $(14.3 \%)$ experienced conflicts several times a week, nearly half of the respondents $(42.3 \%)$ participated in marital conflicts several times a month, and a similar group of people $(43.4 \%)$ several times a year.

The trajectory of conflicts amongst respondents had more integrating (60.6\%) than disintegrating $(22.1 \%)$ impact on the quality of marital relations. The remaining group $(17.4 \%)$ did not define the dominant characteristic of conflict resolution or applied alternating forms of behaviour during disputes. The change of outcome of experienced relationship difficulties were in the similar ratio. The positive for finding consensus effects are the shared by $71.3 \%$ couples, negative ones by $11.3 \%$ of couples, and undefined or mixed, $17.5 \%$ of couples. This means that almost three-quarters of respondents experience greater understanding, trust, increased closeness and cohesion, friendliness and clearing of the air as a result of successfully dealing with difficulties in the relationship. At the same time, they also experienced mutual forgiveness, reconciliation and an increased sense of security. Those left with the negatively charged effects of marital conflicts felt a sense of injustice and mounting tensions and resentments, increased fear, loss of trust, and even a sense of hostility, revenge, or a sense of family breakdown (Ryś, 1994).

The respondents identified the causes of conflicts arising in their marriages using the questionnaire, presented in Table 3. 
Table 3. The causes of marital conflicts of the respondents

\begin{tabular}{|c|c|c|c|c|c|c|c|c|c|c|c|c|}
\hline \multirow[b]{2}{*}{ The causes of conflicts } & \multicolumn{4}{|c|}{ Men } & \multicolumn{4}{|c|}{ Women } & \multicolumn{4}{|c|}{ Both } \\
\hline & $\begin{array}{c}\mathrm{Nev} \\
\mathrm{er}\end{array}$ & $\begin{array}{c}\text { Rare } \\
\text { ly }\end{array}$ & $\begin{array}{c}\text { Som } \\
\mathrm{e} \\
\text { time } \\
\mathrm{s}\end{array}$ & $\begin{array}{l}\text { Oft } \\
\text { en }\end{array}$ & $\begin{array}{c}\mathrm{Nev} \\
\mathrm{er}\end{array}$ & $\begin{array}{c}\text { Rare } \\
\text { ly }\end{array}$ & $\begin{array}{l}\text { Som } \\
\mathrm{e} \\
\text { time } \\
\mathrm{s}\end{array}$ & $\begin{array}{c}\text { Ofte } \\
\mathrm{n}\end{array}$ & $\begin{array}{c}\mathrm{Nev} \\
\mathrm{er}\end{array}$ & $\begin{array}{c}\text { Rare } \\
\text { ly }\end{array}$ & $\begin{array}{l}\text { Som } \\
\mathrm{e} \\
\text { time } \\
\mathrm{s}\end{array}$ & $\begin{array}{c}\text { Ofte } \\
\mathrm{n}\end{array}$ \\
\hline Communication barriers & 30,0 & 42,0 & 23,6 & 4,4 & 30,0 & 43,6 & 20,8 & 5,6 & 30,0 & 42,8 & 22,2 & 5,0 \\
\hline $\begin{array}{l}\text { Lack of attention to build a } \\
\text { mutual relationship }\end{array}$ & 20,8 & 48,8 & 25,2 & 5,2 & 25,2 & 48,8 & 20,0 & 6,0 & 23,0 & 48,8 & 22,6 & 5,6 \\
\hline Sexuality and fertility & 48,0 & 39,6 & 8,8 & 3,6 & 50,0 & 41,6 & 7,2 & 1,2 & 49,0 & 40,6 & 8,0 & 2,4 \\
\hline $\begin{array}{l}\text { Personality and individual } \\
\text { capital }\end{array}$ & 20,8 & 40,8 & 30,8 & 7,6 & 21,6 & 44,8 & 25,6 & 8,0 & 21,2 & 42,8 & 28,2 & 7,8 \\
\hline Houshold chores & 16,8 & 39,2 & 32,4 & 11,6 & 16,4 & 40,0 & 31,6 & 12 & 16,6 & 39,6 & 32,0 & 11,8 \\
\hline Raising children & 25,9 & 42,2 & 19,8 & 12,1 & 23,3 & 48,3 & 19,0 & 9,4 & 24,6 & 42,3 & 19,4 & 10,7 \\
\hline $\begin{array}{l}\text { Relations with the family of } \\
\text { origin }\end{array}$ & 28,0 & 40,0 & 22,8 & 9,2 & 26,0 & 35,2 & 29,6 & 9,2 & 27,0 & 37,6 & 26,2 & 9,2 \\
\hline Illness & 64,8 & 20,0 & 8,8 & 6,4 & 67,6 & 18,8 & 8,8 & 4,8 & 66,2 & 19,4 & 8,8 & 5,6 \\
\hline Life philosophy & 37,2 & 38,8 & 18,4 & 5,6 & 37,2 & 37,6 & 17,6 & 7,6 & 37,2 & 38,2 & 18,0 & 6,6 \\
\hline $\begin{array}{l}\text { Professional and social } \\
\text { work }\end{array}$ & 30,8 & 42,4 & 23,2 & 3,6 & 28,0 & 46,0 & 20,4 & 5,6 & 29,4 & 44,2 & 21,8 & 4,6 \\
\hline
\end{tabular}

The studied couples most often experienced conflicts related to house chores $(11.8 \%$ often, 32\% sometimes and $39.6 \%$ rarely) and to raising children (10.7\% often, $19.4 \%$ sometimes and $42.3 \%$ rarely) (Table 3). Every fourth respondent (27\%) did not raise any issues about the relationship with the family of origin. Three-quarters of respondents argued about this with varying frequency. Conflicts relating to the family of origin were often experienced by every eleventh respondent (9.2\%), by every fourth occasionally $(26.2 \%)$, and rarely by every third respondent (37.6) In a similar ratio, young spouses experienced conflicts over the neglect to grow marital relationship (23\% of the respondents never disagreed on this subject, rarely argued about it: $48.8 \%$ of the respondents, sometimes: $22.6 \%$, and often $5.6 \%$ of the respondents) and their individual and personality characteristics (21.2\% of the respondents never disagreed on this subject, rarely argued about it: $42.8 \%$ of the respondents, sometimes: $28.2 \%$, and often $7.8 \%$ of respondents). For every fifth studied couple, the subject of conflicts arising from time to time were communication barriers (22.2\%) and professional and social work (21.8\%). In more than every fourth respondent, there were no conflicts relating to the aforementioned topics at all (30\% and $29.4 \%$, respectively). Philosophy of life appeared as an important area of misunderstanding between partners. Every third respondent (37.2\%) has never discussed this subject. A similar group of people (38.2\%) rarely argued about it, $18 \%$ sometimes and $6.6 \%$ often. The least differentiated spheres of life were their sexual life and that related to fertility. Half of the 
respondents (49\%) did not experience any conflict relating to the latter's, $40.6 \%$ of people rarely argued with their spouses about it, $8 \%$ did do so sometimes, and $2.4 \%$ often. The fewest conflicts concerned illness. Two thirds of the respondents $(66.2 \%)$ did not experience any conflicts concerning illness. Every fifth respondent (19.4\%) rarely argued about this with their spouse, every eleventh argued sometimes, and 5.6\%, often.

Couples' behaviours during conflicts were assessed in detail (respondents described their conflict resolution strategies - assessing the frequency as never, rarely, sometimes or often - each of the behaviours separately). The scale of these behaviours' data is presented in Table 4.

Table 4. Types of marital conflict behaviours

\begin{tabular}{|c|c|c|c|c|c|c|c|c|c|}
\hline \multirow{3}{*}{$\begin{array}{c}\text { Types of } \\
\text { conflict } \\
\text { behaviours }\end{array}$} & \multicolumn{3}{|c|}{ Men } & \multicolumn{3}{|c|}{ Women } & \multicolumn{3}{|c|}{ Both } \\
\hline & Never & Rarely & Often & Never & Rarely & Often & Never & Rarely & Often \\
\hline & \multicolumn{9}{|c|}{$\%$} \\
\hline \multirow{2}{*}{$\begin{array}{c}\text { Appriopriate } \\
\text { behaviours }\end{array}$} & 0,8 & 32,9 & 66,3 & 0,8 & 20,6 & 78,6 & \multirow{2}{*}{0,8} & \multirow{2}{*}{26,8} & \multirow{2}{*}{72,5} \\
\hline & \multicolumn{6}{|c|}{$\mathrm{U}=28242,00 ; \mathrm{z}=-2,16 ; \mathrm{p}=0,031$} & & & \\
\hline \multirow{2}{*}{$\begin{array}{l}\text { Physically } \\
\text { aggressive } \\
\text { behaviours }\end{array}$} & 63,9 & 31,7 & 4,4 & 64,7 & 31,7 & 3,6 & \multirow{2}{*}{64,3} & \multirow{2}{*}{31,7} & \multirow{2}{*}{4,0} \\
\hline & \multicolumn{6}{|c|}{ n.s. } & & & \\
\hline \multirow{2}{*}{$\begin{array}{l}\text { Verbally } \\
\text { aggressive } \\
\text { behaviours }\end{array}$} & 27,8 & 63,5 & 8,7 & 30,2 & 64,3 & 5,6 & \multirow{2}{*}{29,0} & \multirow{2}{*}{63,9} & \multirow{2}{*}{7,2} \\
\hline & \multicolumn{6}{|c|}{ n.s. } & & & \\
\hline \multirow{2}{*}{$\begin{array}{l}\text { Communication } \\
\text { barriers }\end{array}$} & 14,3 & 70,2 & 15,5 & 15,1 & 69,4 & 15,5 & \multirow{2}{*}{14,7} & \multirow{2}{*}{69,8} & \multirow{2}{*}{15,5} \\
\hline & \multicolumn{6}{|c|}{ n.s. } & & & \\
\hline \multirow{2}{*}{$\begin{array}{l}\text { Inability to } \\
\text { manage } \\
\text { emotions }\end{array}$} & 14,7 & 66,7 & 18,7 & 17,9 & 62,3 & 19,8 & \multirow{2}{*}{16,3} & \multirow{2}{*}{64,5} & \multirow{2}{*}{19,3} \\
\hline & \multicolumn{6}{|c|}{ n.s. } & & & \\
\hline \multirow{2}{*}{$\begin{array}{c}\text { Escaping } \\
\text { behaviours }\end{array}$} & 8,7 & 84,1 & 7,1 & 8,7 & 87,3 & 4,0 & \multirow{2}{*}{8,7} & \multirow{2}{*}{85,7} & \multirow{2}{*}{5,6} \\
\hline & & $\mathrm{U}=286^{3}$ & $50 ; z$ & 1,$92 ; \mathrm{r}$ & $=0,05$ & & & & \\
\hline \multirow{2}{*}{$\begin{array}{l}\text { Competitive } \\
\text { behaviours }\end{array}$} & 23,4 & 66,7 & 9,9 & 25,4 & 68,3 & 6,3 & & & \\
\hline & & & & S. & & & & & \\
\hline Engaging third & 50,8 & 44,0 & 5,2 & 48,4 & 47,6 & 4,0 & & & \\
\hline conflict & & & & & & & (T, & T, & 4,0 \\
\hline
\end{tabular}

Taking into account a detailed analysis of the surveyed young spouses' behaviours in conflict situations, it turned out that the right approaches to disputes were manifested by the majority of the respondents (Table 4 ). $72.5 \%$ of the respondents $(66.3 \%$ of men and $78.6 \%$ of women) responded often in a right manner. They used behaviours such as presenting their arguments, listening to their partners with understanding; endeavouring to better understand matters relating to them, reflecting on a problem, negotiating, admitting guilt, seeking consent, agreement, compromise, apologizing and forgiving. This data largely 
confirmed the results obtained on the scales determining the trajectory and effects of conflicts (Table 2).

Over one third of respondents (35.7\%) experienced a spousal physical aggression during conflicts (hitting, throwing objects, pushing, damaging property, sexual violence, and being thrown out of the house). Usually this happened rarely $(31.7 \%)$, although in $4 \%$ of respondents such behaviour was experienced, using such forms as criticism, malicious remarks, insults, irony, ridicule, loud condemnation of the partner's behaviour, humiliation, hooking on to their partner's stumbles, undermining their feelings and experiences, accusations, verbal and life threats. Verbal abuse amongst $7.2 \%$ of couples was frequent; among $63.9 \%$ of couples, it was rare, and never occurred among $29 \%$ of couples.

Communication barriers were in use by the respondents rarely. Such forms of reaction as interrupting the partner's statements, recalling mistakes, formulating excessive generalizations, exaggerating errors, blaming each other or distorting statements occurred often in $15.5 \%$ of the respondents, rarely in $69.8 \%$ and were never experienced by $14.7 \%$ of respondents.

The tension that arises when experiencing conflicts is often associated with an inability to control emotions. Every fifth respondent (19.3\%) revealed uncontrolled emotions often, and this was rarely seen in $64.5 \%$ of people. The inability to deal with emotions respondents expressed through showing impatience, shouting and vulgarisms, initiating quarrels, venting anger or coldness. Every sixth respondent $(16.3 \%)$ indicated that they can control their emotions quite well in difficult situations.

The main core of respondents $(85.7 \%)$ rarely undertook escape behavior in conflict situations, and $8.7 \%$ of the respondents never did so. Only $5.6 \%$ of the respondents, slightly more often men than women, often escaped in a marital conflict situations. When it happened, they sometimes avoided conflicts, expressed reluctance to talk to a partner, caved in to their spouse, remained silent, i.e. by applying "quiet days", deny personal guilt, deny the existence of a conflict, surrender to pressure, abandon their own beliefs, withdrawal, downplay the situation, or leave the house.

Competitive behaviour was not undertaken by every fourth respondent (24.4\%). Two thirds of the respondents $(67.5 \%)$ did so rarely, and $8.1 \%$ used such responses frequently. These behaviours were manifested in the lack of willingness to understand the partner, clear opposition to them, attacking their most touching sensitivities, disrespecting joint decisions and commitments, carrying on regardless of what the partner says, in the fight for dominance, in competitive behaviour or resisting reaching out to them.

Almost half of the respondents (45.8\%) rarely (consciously or unconsciously) engaged third parties in the conflict and $4.6 \%$ did it often. When the latter happened, they sometimes complained in front of children, argued fiercely in front of third parties, sought support for 
their position from relatives or friends. Half of the respondents $(49.6 \%)$ have never resolved conflicts in the third parties presence.

In the last part of the studies, an analysis was made of the relationship between the respondents' assessment of the environment of the family of origin and their coping with conflicts in their own marriages. Data on this subject are presented in Tables 5, 6 and 7.

Table 5. Intensity of cohesion in the Family of Origin and the ways of dealing with conflicts in adulthood

\begin{tabular}{|c|c|c|c|c|c|c|}
\hline \multirow{4}{*}{ Dealing with conflicts in adulthood } & \multicolumn{6}{|c|}{ The measure of intensity of cohesion in the Family of Origin } \\
\hline & \multicolumn{2}{|c|}{ Disintegration } & \multicolumn{2}{|c|}{ Balance Cohesion } & \multicolumn{2}{|c|}{ Enmeshment } \\
\hline & Men & Women & Men & Women & Men & Women \\
\hline & \multicolumn{6}{|c|}{ Spearman's rho } \\
\hline Frequency of conflitcs & $-0,19 * *$ & $-0,14^{*}$ & 0,11 & 0,08 & $-0,19 * *$ & $-0,10$ \\
\hline Trajectory of conflicts & $-0,28 * * *$ & $-0,25$ & $0,12^{*}$ & $0,20 * *$ & $-0,31^{* * *}$ & $-0,20 * *$ \\
\hline Effect of conflicts & $-0,36^{* * *}$ & $-0,20^{* *}$ & $0,22^{* * *}$ & $0,19^{* *}$ & $-0,34^{* * *}$ & $-0,13^{*}$ \\
\hline Appropriate conflict behaviours & $-0,21^{* * *}$ & $-0,27^{* * *}$ & $0,19^{* *}$ & $0,30 * * *$ & $-0,27^{* * *}$ & $-0,20 * *$ \\
\hline Physically aggressive behaviours & $0,27^{* * *}$ & $0,24^{* * *}$ & $-0,14^{*}$ & $-0,21^{* * *}$ & $0,31^{* * *}$ & $0,12^{*}$ \\
\hline Verbally aggressive behaviours & $0,30 * * *$ & $0,23^{* * *}$ & $-0,20 * *$ & $-0,19 * *$ & $0,30 * * *$ & $0,13^{*}$ \\
\hline Communication barriers in conflict & $0,27^{* * *}$ & $0,22^{* * *}$ & $-0,13^{*}$ & $-0,17^{* *}$ & $0,21^{* * *}$ & 0,08 \\
\hline Inability to manage emotions in conflicts & $0,28^{* * *}$ & $0,24^{* * *}$ & $-0,18^{* *}$ & $-0,18^{* *}$ & $0,20 * *$ & 0,09 \\
\hline Escaping behaviours in conflicts & $0,15^{*}$ & $0,21^{* * *}$ & $-0,05$ & $-0,13^{*}$ & $0,15^{*}$ & $0,11^{\mathrm{a}}$ \\
\hline Competitive behaviors in conflict & $0,31^{* * *}$ & $0,24^{* * *}$ & $-0,15^{*}$ & $-0,21^{* * *}$ & $0,27^{* * *}$ & $0,11^{\mathrm{a}}$ \\
\hline Engaging third parties in conflict & $0,20 * *$ & $0,16^{* *}$ & $-0,15^{*}$ & $-0,15^{*}$ & $0,27^{* * *}$ & 0,08 \\
\hline
\end{tabular}

${ }^{* * *} \mathrm{p}<.001 .{ }^{* *} \mathrm{p}<.01 .^{*} \mathrm{p}<.05$

Table 6a. Intensity of flexibility in the Family of Origin and the ways of dealing with conflicts in adulthood

\begin{tabular}{|c|c|c|c|c|c|c|}
\hline \multirow{4}{*}{ Dealing with conflicts in adulthood } & \multicolumn{6}{|c|}{ Measure of intensity of flexibility in the Family of Origin } \\
\hline & \multicolumn{2}{|c|}{ Rigidity } & \multicolumn{2}{|c|}{ Balanced flexibility } & \multicolumn{2}{|c|}{ Chaos } \\
\hline & Men & Women & Men & Women & Men & Women \\
\hline & \multicolumn{6}{|c|}{ Spearman's rho } \\
\hline Frequency of conflitcs & $-0,13^{*}$ & $-0,09$ & $0,13^{*}$ & 0,01 & $-0,11^{\mathrm{a}}$ & $-0,14^{*}$ \\
\hline Trajectory of conflicts & $-0,15^{*}$ & $-0,10$ & $0,11^{\mathrm{a}}$ & $0,15^{*}$ & $-0,24^{* * *}$ & $-0,24^{* * *}$ \\
\hline Effect of conflicts & $-0,18^{* *}$ & $-0,11^{\mathrm{a}}$ & $0,23 * * *$ & 0,07 & $-0,31^{* * *}$ & $-0,14^{*}$ \\
\hline Appropriate conflict behaviours & $-0,13^{*}$ & $-0,09$ & $0,14^{*}$ & $0,18^{* *}$ & $-0,21^{* * *}$ & $-0,09$ \\
\hline Physically aggressive behaviours & $0,14^{*}$ & $0,11^{\mathrm{a}}$ & $-0,05$ & $-0,14^{*}$ & $0,23^{* * *}$ & $0,13^{*}$ \\
\hline Verbally aggressive behaviours & $0,17^{* *}$ & 0,06 & $-0,12^{*}$ & $-0,11^{a}$ & $0,24^{* * *}$ & $0,13^{*}$ \\
\hline
\end{tabular}


Table $6 \mathrm{~b}$. Intensity of flexibility in the Family of Origin and the ways of dealing with conflicts in adulthood

\begin{tabular}{|l|l|l|l|l|l|l|}
\hline \multirow{2}{*}{ Dealing with conflicts in adulthood } & \multicolumn{6}{|c|}{ Measure of intensity of flexibility in the Family of Origin } \\
\cline { 2 - 7 } & \multicolumn{2}{|c|}{ Rigidity } & \multicolumn{5}{c|}{ Balanced flexibility } & \multicolumn{2}{c|}{ Chaos } \\
\cline { 2 - 7 } & \multicolumn{1}{|c|}{ Men } & Women & Men & Women & Men & Women \\
\cline { 2 - 7 } & \multicolumn{5}{|c|}{ Spearman's rho } \\
\hline Communication barriers in conflict & $0,17^{* *}$ & 0,07 & $-0,10$ & $-0,13^{*}$ & $0,19^{* *}$ & $0,11^{\mathrm{a}}$ \\
\hline Inability to manage emotions in conflicts & $0,16^{* *}$ & 0,09 & $-0,20^{* *}$ & $-0,14^{*}$ & $0,19^{* *}$ & 0,12 \\
\hline Escaping behaviours in conflicts & 0,09 & 0,10 & $-0,06$ & $-0,07$ & $0,15^{*}$ & $0,16^{* *}$ \\
\hline Competitive behaviors in conflict & $0,12^{*}$ & 0,08 & $-0,11^{\mathrm{a}}$ & $-0,09$ & $0,24^{* * *}$ & $0,13^{*}$ \\
\hline Engaging third parties in conflict & $0,23^{* * *}$ & 0,06 & $-0,04$ & $-0,13^{*}$ & $0,28^{* * *}$ & $0,11^{\mathrm{a}}$ \\
\hline
\end{tabular}

${ }^{* * *} \mathrm{p}<.001 .{ }^{* *} \mathrm{p}<.01 .{ }^{*} \mathrm{p}<.05$

Table7. The Quality of communication and the level of satisfaction of growing up in the Family of Origin

\begin{tabular}{|c|c|c|c|c|}
\hline \multirow{3}{*}{ Managing conflicts in adulthood } & \multicolumn{2}{|c|}{$\begin{array}{l}\text { Communication in the } \\
\text { Family of Origin }\end{array}$} & \multicolumn{2}{|c|}{$\begin{array}{l}\text { Life satisfaction on the } \\
\text { Family of Origin }\end{array}$} \\
\hline & Men & Women & Men & Women \\
\hline & \multicolumn{4}{|c|}{ rho Spearmana } \\
\hline Frequency of conflitcs & $0,17^{* *}$ & 0,07 & $0,12^{*}$ & $0,11^{\mathrm{a}}$ \\
\hline Trajectory of conflicts & $0,21^{\text {*** }}$ & $0,21^{* * *}$ & $0,21^{* * *}$ & $0,17^{* *}$ \\
\hline Effect of conflicts & $0,28^{* * *}$ & $0,18^{* *}$ & $0,28^{* * *}$ & $0,19 * *$ \\
\hline Appropriate conflict behaviours & $0,14^{*}$ & $0,21^{* * *}$ & $0,18^{* *}$ & $0,14^{*}$ \\
\hline Physically aggressive behaviours & $-0,13^{*}$ & $-0,20 * *$ & $-0,15^{*}$ & $-0,15^{*}$ \\
\hline Verbally aggressive behaviours & $-0,21^{* * *}$ & $-0,24^{* * *}$ & $-0,23^{* * *}$ & $-0,18^{* *}$ \\
\hline Communication barriers in conflict & $-0,18^{* *}$ & $-0,24^{* * *}$ & $-0,24^{* * *}$ & $-0,23^{* * *}$ \\
\hline Inability to manage emotions in conflicts & $-0,27^{* * *}$ & $-0,25^{* * *}$ & $-0,29 * * *$ & $-0,20 * *$ \\
\hline Escaping behaviours in conflicts & $-0,10$ & $-0,13^{*}$ & $-0,14^{*}$ & $-0,14^{*}$ \\
\hline Competitive behaviors in conflict & $-0,22^{* * *}$ & $-0,23^{* * *}$ & $-0,21^{* * *}$ & $-0,19 * *$ \\
\hline Engaging third parties in conflict & $-0,15^{*}$ & $-0,14^{*}$ & $-0,17^{* *}$ & $-0,18^{\star *}$ \\
\hline
\end{tabular}

${ }^{* * *} \mathrm{p}<.001 .{ }^{* *} \mathrm{p}<.01 .{ }^{*} \mathrm{p}<.05$

The cohesion of the family of origin proved to be a significant variable for the analysis of its relationship with the way respondents' raised in these families dealt with conflict resolution in adulthood (Table 5). The higher the level of balanced family cohesion, the more often men and women resolved disputes $s$ in a constructive manner, and the conflict resolution trajectory had an integrating relational character. They were more likely to engage in the right behaviours. The strength of the correlation turned out to be greater for 
the surveyed women $($ rho $=0.30)$ than for men $($ rho $=0.19)$. They were less aggressive, both physically and verbally, they applied communication barriers less often, they managed to control their emotions during the escalation of conflicts more often, and they competed less often with each other in conflict situations and less often embroiled third parties in to the conflict. Additionally, women from such families were less likely to run away from conflict resolution.

Growing up in families with extremely low cohesion, that is, homes with high levels of disengagement, or homes with extremely high level of cohesion, i.e. homes with high levels of enmeshment, was not conducive to coping properly with marital conflicts in adulthood. The higher the level of disengagement or confusion in families, the more often respondents experienced conflicts in their own marital relationships. They are more often engaged in destructive behaviours during conflict resolution, which ultimately disintegrated their marital relationship. Stronger relationships between the variables analysed emerged in the case of the surveyed men as opposed to women. The respondents' failure to properly deal with the marital disputes manifested itself as a more frequent aggressive behaviour, both physical and verbal. The correlation between these variables was more pronounced, as was the case above, in the group of men compared to the surveyed women. A high level of disintegration had a positive correlation both for the surveyed men and women, and enmeshment in the case of the surveyed men also correlated with the use of communication barriers, escaping and competitive behaviours as well as failure to cope with emotions and embroiling third parties in to the conflict.

The analysis of the relations between the level of flexibility in the respondents' family of origin and the ways of coping with conflicts in their own marriages showed some differentiation both in terms of strength and gender of the respondents, for which statistically significant correlations were observed (Table 6). The higher the level of balanced flexibility in the families of the surveyed men, the less often they experienced conflicts with their own spouses, and if they did occur, they resolved them more often in a constructive manner (at the level of tendencies), they more often applied behaviors leading to integrating the spouses when solving communication difficulties arose. At the same time, they were characterized by a greater ability to deal with emotions during marital disagreements.

Furthermore, men from extremely low flexibility homes, i.e. the so-called high score rigidity families, as well as homes of extremely high flexibility, i.e. homes with a high level of chaos had greater difficulties in resolving conflicts in the right manner than those growing up in homes with balanced flexibility. More often than in well-functioning families, men from both types of environments, founded by the so-called rigid and chaotic families, more often experienced conflicts with their wives, and more often resolved them in a destructive way leading to disintegration of their relationships. Less frequently they applied right 
behaviours leading to conflict resolution, and more often physical and verbal abuse. During difficult conversations concerning conflicts, they more often exhibited issues with controlling their emotions, communication barriers and attempts to resolve conflicts in the presence of third parties. Moreover, men from families with a high level of chaos more often than others engaged in running away from a conflict situations. The obtained data showed stronger relationships between descents from families with a high level of chaos compared to those from families with a high level of rigidity.

In the conducted studies, correlations were found between growing up in families with a high level of rigidity and the behaviours applied by women in marital conflict resolution, which were not statistically significant. Just at the level of tendencies, the disintegrating effects of their behaviour during conflicts with their husbands and the tendency to physical aggression towards them were noticed. When analysing the relation between so-called, a high level of enmeshment families of origin, with the ways of dealing with conflicts in one's own marriage, concluded that it was manifested in several analysed variables. The higher the level of chaos in the women's families of origin, the more often they experienced conflicts with their husbands. These disputes were more often destructive and were associated with experiencing disintegrating effects in their relationships. These women more often than others had difficulties in coping with emotions, submitted their husbands to a physical and verbal abuse, as well as competitive or escaping behaviour. Correlations, at the trends level, were also concluded between ascending from a high level of chaos families and the use of communication barriers and conflict resolution in the presence of third parties.

Growing up in families with a high level of communication contributes to a statistical significance of the majority of variables describing the man and woman's coping methods (Table 7). The higher the level of communication in the families of origin, the better the respondents dealt with marital conflict resolution. Their outcomes were more often constructive and associated with behaviours integrating the spouses' relationship. Both of them more often exhibited right behaviours, associated with a significantly lower tendency to physical and verbal aggression than respondents from homes with a poor communication. They used communication barriers, competitive behaviours and inclusion of other people in conflicts less often, and in the case of women, escape behaviours were also rare. At the same time, the respondents who grew up in families communicating well, coped with their emotions better than others during disputes with their spouses.

Respondents satisfied with the quality of the atmosphere in the homes of origin (both in terms of cohesion, flexibility and communication) were much better at resolving conflicts in their own marriages. Their disputes were less frequent compared to those dissatisfied with the quality of life in families of origin. The correlations obtained confirmed that the higher the level of satisfaction with growing up in their family homes, the better and more 
constructive their behaviour during conflict resolution. They felt a sense of the integrating nature of reconciliation, rarely employed physical and verbal aggression towards each other, they coped better with emotions in these situations, rarely introduced communication barriers or escape or competitive behaviours. Concomitantly they also solved problem situations without the participation of third parties, more frequently.

Similarly to the above conclusions, the poorer the communication in the families of origin and the lower the level of respondents' satisfaction with their life when growing up in them, the more frequent conflicts in their own marriages, and the ways to solve them more often took a destructive form, leading to the disintegration of their relationships.

\section{Conclusions of the research}

In all studies undertaken by the researchers' on the strength of the influence of the generational family on its growing members, data confirms a correlation. The research presented in this article, made it possible to prove that the quality of family systems and the ties and relations between their members are largely reflected in the quality of marriages created by adult children growing up in these systems.

The data obtained in the research concludes that the atmosphere of emotional closeness, a sense of family community, mutual trust, allowance to be open to all persons in the family and sharing their emotions and needs during communication, and at the same time respect for the sense of individuality and for the boundaries between family members, defined by the author of the Circle Model, Olson, as a balanced coherence and flexibility enables shaping the psychosocial abilities of people living in such families in various life situations, including experiencing their own marital conflicts in adulthood. The results of the research confirmed that the higher the level of cohesion, flexibility and communication in generational families, as well as the sense of satisfaction with life in these environments, the less frequently in adulthood individuals from such families experienced marital conflicts. Nevertheless, when conflicts occurred more often, they managed to solve them in a constructive manner, allowing for integration with partners, and sensing the effects of emerging disputes in a positive way. Sadly, only a small number of respondents grew up in families with a high level of balanced cohesion and flexibility. More than half of them experienced high levels of disengagement or enmeshment, and rigidity or chaos. Half of the respondents grew up in homes with a poor communication, and every third was not satisfied with life in their family homes. As a result, those who grew up in homes of an extreme values of closeness, either too great or too small, and the sense of individuality was stifled or there was a sense of disengagement with loved ones, at the same time the boundaries were too tight or too loose, and the roles and rules too rigid or unclear and inconsistent, they suffered the consequences of the process of generational transmission and, 
as they grew up in unbalanced systems, they experienced in adulthood many relational difficulties with their own spouses. It transpired the higher the level of disengagement or confusion, as well as the rigidness or chaos in the generational families, the lower the poorer the communication between their members and the lower the level of satisfaction with life in these families, the more often in adulthood they experienced marital conflicts. These disputes were usually destructive and had a disintegrating effect on their relationships. Physical and verbal abuse, communication barriers and competitive behaviours were among the most common behaviours adopted during conflict resolution by respondents growing up in such homes. Although slightly less frequently, they also experienced escaping behaviours or embroiling third parties in the conflict. These respondents more often also failed to control their emotions. A greater correlation of this type of behaviours with the assessment of ties and relationships in the family of origin was found in the population of the surveyed men than in women.

To answer the research problem posed in the methodological part, it can be advised that the quality of ties and relations in families of origin largely determines the way spouses cope with conflicts in their own marriages. A lower frequency of marital conflicts and their satisfactory resolution is favoured by being brought up in homes with a high level of cohesion, flexibility and communication, as well as a sense of satisfaction with growing up in such families, while the increased frequency of conflicts and the tendency to resolve them in a destructive and disintegrating way is more often associated with growing up in homes with a low level of cohesion and flexibility and a low level of communication in the families of origin, which at the same time determine the feeling of dissatisfaction with living in them.

The conclusions hereby presented constitute an important premise for looking for ways to break the cycle of generational transmission, especially in the case of those spouses who imitate such patterns of their parents' behaviour in conflict resolution that lead to their own relationship breakup. One of such ways could be to conduct educational activities among married couples on the determinants of the quality of marital relations and practical ways of strengthening it. T. Asha Jyothi et al. (2020) studied the effects of education focused on communication skills training and found that the vast majority of participating spouses significantly improved the quality of their relationships and ultimately their marital conflicts were also significantly reduced.

Translated by dr Renata Towlson

\section{Bibliography:}

Arora, E., Deepti, S.S., Singh, T., Lal, M. (2019). Impact of marital conflicts and domestic violence on occurrence of depression in married women - a cross-sectional study, Global Journal for Research Analysis, 3 (8), 60-62. 
Bandura, A. (2007). Teoria społecznego uczenia sie, Warszawa: Wydawnictwo Naukowe PWN.

Bieńko, M. (2008-2009). Współczesne skrypty bycia razem. Zamierzony i realizowany projekt scenariuszy ról małżeńskich, Roczniki Socjologii Rodziny, 19, 71-90.

Chełpa, S., Witkowski, T. (2015). Psychologia konfliktów, Wrocław: Wydawnictwo Bez Maski.

Cassibba, R., Coppola, G., Sette, G., Curci, A., Costantini, A. (2017). The transmission of attachment across three generations: A study in adulthood, Developmental Psychology, 2 (53), 396-405, doi: https:// doi.org/10.1037/dev0000242.

Czyżowska, D. (2009). Konflikt, (w:) J. Siuta (red.), Stownik psychologii, 126-127, Kraków: Krakowskie Wydawnictwo Naukowe.

Da Costa, C.B., Falcke, D., Mosmann, C.P. (2015). Marital conflicts in long-term marriages: motives and feelings, Psicologia em Estudo, 3 (20), 411-423.

Davies, P.T., Coe, J.L., Martin, M.J., Sturge-Apple, M.L., Cummings, E.M. (2015). The developmental costs and benefits of children's involvement in interparental conflict, Developmental Psychology, 8 (51), 1026-1047, doi: https:/ / doi.org/10.1037/dev0000024.

Doliński, A. (2004). Zachowania młodzieży w sytuacjach społecznych jako transmisja wzorów rodzinnych, Kraków: Oficyna Wydawnicza „Impuls”.

Finn, C., Johnson, M.D., Neyer, F.J. (2020). Happily (n)ever after? Codevelopment of romantic partners in continuing and dissolving unions, Developmental Psychology, 5 (56), 1022-1028, doi: https:// doi.org/10.1037/dev0000897.

Fischaleck, F. (1990). Uczciwa kłótnia małżeńska, Warszawa: Instytut Wydawniczy PAX.

French, K.A., Allen, T.D. (2020). Episodic work-family conflict and strain: A dynamic perspective. Journal of Applied Psychology, 8 (105), 863-888, doi: https:// doi.org/10.1037/ap10000470.

Fosco, G.M., Bray, B.C. (2016). Profiles of cognitive appraisals and triangulation into interparental conflict: Implications for adolescent adjustment. Journal of Family Psychology, 5 (30), 533-542, doi: https:// doi.org/10.1037/ fam0000192.

Gałkowska, A. (1999). Percepcja powodzenia matżeństwa rodziców a społeczny obraz siebie ich dorostych dzieci, Lublin: Towarzystwo Naukowe KUL.

Ha, T., Otten, R., McGill, S., Dishion, T.J. (2019). The family and peer origins of coercion within adult romantic relationships: A longitudinal multimethod study across relationships contexts. Developmental Psychology, 1 (55), 207-215.

https:// doi.org/10.1037/dev0000630.

Haris, F., Kumar, A. (2018). Marital Satisfaction and Communication Skills among Married Couples. Indian Journal of Social Research, 1 (59), 35-44.

Harwas-Napierała, B. (2008). Komunikacja interpersonalna w rodzinie, Poznań: Wydawnictwo Naukowe Uniwersytetu im. Adama Mickiewicza.

Jambon, M., Madigan, S., Plamondon, A., Jenkins, J. (2019). Developmental trajectories of physical aggression and prosocial behavior in early childhood: Family antecedents 
and psychological correlates, Developmental Psychology, 6 (55), 1211-1225, doi: https:// doi.org/10.1037/dev0000714.

Jyothi, T.A., Devi, M.S., Sreedevi, P., Rani, R.N., Supraja, T. (2020). Effect of family life education on marital satisfaction of married couple, The Pharma Innovation Journal, 8 (9), 10-14.

Kazmierski, K.F.M., Beam, C.R., Margolin, G. (2020). Family aggression and attachment avoidance influence neuroendocrine reactivity in young adult couples, Journal of Family Psychology, 6(34), 664-675, doi: https://doi.org/10.1037/fam0000633.

Kluwer, E.S., Van der Wal, R.C., Visser, M., Finkenauer, C. (2020). Predictors of forgiveness among divorced parents, Journal of Family Psychology, 3, Advance online publication, doi: https://doi.org/10.1037/fam0000799.

Knoester, C. (2003). Implications of Childhood Externalizing Problems for Young Adults, Journal of Marriage and Family, 4 (65), 1073-1079.

Komorowska-Pudło, M. (2019), Środowisko wychowawcze domu rodzinnego a relacje matżeńskie w dorostym życiu, Kraków: Wydawnictwo Naukowe Akademii Ignatianum.

Korol, E. (2015). Wzorce funkcjonowania rodziny pochodzenia a inteligencja emocjonalna młodych dorosłych, Studia Psychologica, 1 (15), 19-32.

Kouneski, E.F. (2000). Family Assessment and the Circumplex Model: New Research Developments and Applications, University of Minnesota, Twin Cities, Minnesota, za: http:/ / citeseerx.ist.psu.edu/viewdoc/download?doi=10.1.1.195.3412\&rep=rep1\&typ e=pdf (dostęp: 15.03.2017).

Lavner, J.A., Karney, B.R., Bradbury, T.N. (2016). Does Couples' Communication Predict Marital Satisfaction, or Does Marital Satisfaction Predict Communication?, Journal of Marriage and Family, 3 (78), 680-694.

Lawson, M., Speidel, R., Fondren, K., Cummings, E.M., Valentino, K. (2020). Intimate partner violence and maltreated preschoolers' internal representations of conflict, Journal of Family Psychology, 4 (34), 425-435, doi: https:/ / doi.org/10.1037/fam0000627.

Li, X., Cao, H., Zhou, N., Ju, X., Lan, J., Zhu, Q., Fang, X. (2018). Daily communication, conflict resolution, and marital quality in Chinese marriage: A three-wave, crosslagged analysis, Journal of Family Psychology, 6 (32), 733-742, doi: https:// doi.org/10.1037/fam0000430.

Lucas-Thompson, R.G., Granger, D.A. (2014). Parent-child relationship quality moderates the link between marital conflict and adolescents' physiological responses to social evaluative threat. Journal of Family Psychology, 4 (28), 538-548, doi: https:// doi.org/10.1037/a0037328.

Mahoney, A., Pargament, K.I., DeMaris, A. (2020). Spiritual intimacy, spiritual oneupmanship, and marital conflict across the transition to parenthood, Journal of Family Psychology, Advance online publication, doi: https:// doi.org/10.1037/fam0000795. 
Margasiński, A. (2011). Model Kołowy i skale FACES jako narzędzie badania rodziny. Historia, rozwój i zastosowanie, Częstochowa: Akademia im. J. Długosza.

Margasiński, A. (2013). Skale Oceny Rodziny. Podręcznik, Warszawa: Pracownia Testów Psychologicznych Polskiego Towarzystwa Psychologicznego.

Martowska, K. (2015). Cechy rodziny pochodzenia a przystosowanie społeczno-emocjonalne młodych kobiet, (w:) A. Margasiński (red.), Rodzina w ujęciu systemowym. Teoria $i$ badania, 33-51, Warszawa: Pracownia Testów Psychologicznych Polskiego Towarzystwa Psychologicznego.

Mastrotheodoros, S., Van Lissa, C.J., Van der Graaff, J., Deković, M., Meeus, W.H. J., Branje, S.J.T. (2020). Day-to-day spillover and long-term transmission of interparental conflict to adolescent-mother conflict: The role of mood, Journal of Family Psychology, 8 (34), 893-904, doi: https:/ / doi.org/10.1037/ fam0000649.

Mbwirire, J. (2017). Causes of marital conflicts in Christian Marriages in Domboshava Area, Maschonaland East Province, Zimbabwe, International Journal of Humanities, Art and Social Studies, 1 (2), 59-73.

McCauley, D.M., Sloan, C.J., Xia, M., Fosco, G.M. (2021). Same family, divergent realities: How triangulation preserves parents' illusory harmony while adolescents navigate interparental conflicts. Journal of Family Psychology, 2 (35), 128-137, doi: https:// doi.org/10.1037/fam0000785.

McKernan, C.J., Lucas-Thompson, R.G. (2018). Autonomic nervous system coordination moderates links of negative interparental conflict with adolescent externalizing behaviors. Developmental Psychology, 9 (54), 1697-1708, doi: https:// doi.org/10.1037/dev0000498.

Neysari, M., Bodenmann, G., Mehl, M.R., Bernecker, K., Nussbeck, F.W., Backes, S., Zemp, M., Martin, M., Horn, A.B. (2016). Monitoring pronouns in conflicts: Temporal dynamics of verbal communication in couples across the lifespan. GeroPsych: The Journal of Gerontopsychology and Geriatric Psychiatry, 4 (29), 201-213, doi: https:// doi.org/10.1024/1662-9647/a000158.

Olson, D.H. (2000). Circumplex Model of Marital and Family Systems, Journal of Family Therapy, 1-22, za:

http://eruralfamilies.uwagec.org/ERFLibrary/Readings/CircumplexModelOfMarit alAndFamilySystems.pdf (dostęp: 13.03.2018).

Olson, D.H. (2004). Family Satisfaction Scale, Minneapolis: Life Innorations, za: http://www.laviecounseling.org/vfh/vfhasm/FACESIV.FamilySatisfactionScale.pd f (dostęp: 13.03.2018).

Olson, D.H. (2013). Kwestionariusz FACES IV i Model Kołowy. Badanie walidacyjne, Warszawa: Pracownia Testów Psychologicznych Polskiego Towarzystwa Psychologicznego.

Omidi, A., Talighi, E. (2017). Prediction couple's marital satisfaction based on emotion 
regulation. International Journal of Educational \& Psychological Researches, 3 (3), 157-162.

Otero, M.C., Wells, J.L., Chen, K.H., Brown, C.L., Connelly, D.E., Levenson, R.W.,

Fredrickson, B.L. (2020). Behavioral indices of positivity resonance associated with

long-term marital satisfaction. Emotion, 7 (20), 1225-1233, doi:

https:// doi.org/10.1037/emo0000634.

Overbeek, G., Stattin, H. (2007). Parent-child Relationships, Partner Relationships, and Emotional Adjustment: A Birth-to-maturity Prospective Study, Developmental Psychology, 2 (43), 429-437.

Parry, L.Q., Davies, P.T., Sturge-Apple, M.L., Coe, J.L. (2020). Coparental discord and children's behavior problems: Children's negative family representations as an explanatory mechanism, Journal of Family Psychology, 5 (34), 523-533, doi: https:// doi.org/10.1037/fam0000638.

Parsons, J.A., Prager, K.J., Wu, S., Poucher, J.W., Hansen, M.P., Shirvani, F. (2020). How to kiss and make-up (or not!): Postconflict behavior and affective recovery from conflict, Journal of Family Psychology, 1 (34), 35-45, doi: https:/ / doi.org/10.1037/ fam0000579.

Radochoński, M. (1999). Systemowa charakterystyka środowiska rodzinnego wielokrotnych sprawców czynów przestępczych, Roczniki Socjologii Rodziny, 11, 155-173.

Rostowska, T. (1995). Transmisja międzypokoleniowa w rodzinie w zakresie wybranych wymiarów osobowości, Łódź: Wydawnictwo Uniwersytetu Łódzkiego.

Rostowska, T. (2001). Konflikt międzypokoleniowy w rodzinie: analiza psychologiczna, Łódź: Wydawnictwo Uniwersytetu Łódzkiego.

Rothenberg, W.A., Hussong, A.M., Chassin, L. (2018). Intergenerational continuity in highconflict family environments: Investigating a mediating depressive pathway. Developmental Psychology, 2 (54), 385-396, doi: https:// doi.org/10.1037/dev0000419.

Ryś, M. (1994). Konflikty w rodzinie, nisza czy budują? Warszawa: Centrum Metodyczne Pomocy Psychologiczno-Pedagogicznej MEN.

Ryś, M., Greszta, E., Grabarczyk, K. (2019). Intelektualna, emocjonalna i działaniowa bliskość małżonków a ich gotowość do rozwiązywania konfliktów oraz przebaczania, Kwartalnik Naukowy Fides et Ratio, 2 (38), 221-253.

Schaffer, R. (2021). Psychologia dziecka, Warszawa: Wydawnictwo Naukowe PWN.

Seiter, N.S., Lucas-Thompson, R.G., Graham, D.J. (2019). Interparental conflict moderates the association between neighborhood stress and adolescent health, Journal of Family Psychology, 2 (33), 253-258, doi: https:// doi.org/10.1037/fam0000500.

Sokolovic, N., Leckie, G., Browne, D.T., Jenkins, J.M. (2021). What makes for responsive family interactions? Disentangling individual, family-level, and socioeconomic contributions, Journal of Family Psychology, Advance online publication, doi: https:// doi.org/10.1037/fam0000685. 
Stewart, J., Logan, C. (2021). Negocjowanie obrazu własnej osoby, (w:) J. Stewart (red.), Mosty zamiast murów. Podręcznik komunikacji interpersonalnej, 318-331, Warszawa: Wydawnictwo Naukowe PWN.

Van Eldik, W.M., De Haan, A.D., Parry, L.Q., Davies, P.T., Luijk, M.P.C.M., Arends, L.R., Prinzie, P. (2020). The interparental relationship: Meta-analytic associations with children's maladjustment and responses to interparental conflict, Psychological Bulletin, 7 (146), 553-594, doi: https:/ / doi.org/10.1037/bul0000233.

Warmuth, K.A., Cummings, E.M., Davies, P.T. (2020). Constructive and destructive interparental conflict, problematic parenting practices, and children's symptoms of psychopathology, Journal of Family Psychology, 3 (34), 301-311, doi: https:// doi.org/10.1037/fam0000599.

Weymouth, B.B., Fosco, G.M., Mak, H.W., Mayfield, K., LoBraico, E.J., Feinberg, M.E. (2019). Implications of interparental conflict for adolescents' peer relationships: A longitudinal pathway through threat appraisals and social anxiety symptoms, Developmental Psychology, 7 (55), 1509-1522, doi: https:// doi.org/10.1037/dev0000731.

Wilmot, W.W, Hocker, J.L. (2011). Konflikty między ludźmi, Warszawa: Wydawnictwo Naukowe PWN.

Young, J.E., Klosko, J.S., Weishaar, M.E. (2015). Terapia schematów. Przewodnik praktyka, Sopot: Gdańskie Wydawnictwo Psychologiczne. 